\author{
MAGDALENA SEMCZYSZYN \\ https://orcid.org/0000-0003-4933-4346 \\ Instytut Pamięci Narodowej, Szczecin
}

\title{
PACYFIKACJA PIĘCIU WSI. O CIEMNYCH KARTACH BIOGRAFII KAPITANA ROMUALDA RAJSA „BUREGO”*
}

\begin{abstract}
Abstrakt: Biografia kpt. Romualda Rajsa „Burego" autorstwa Michała Ostapiuka opowiada o życiu jednego z żołnierzy wileńskiej konspiracji Armii Krajowej z czasów okupacji niemieckiej, który po wojnie kontynuował działalność zbrojną na terenie Białostocczyzny, walcząc w szeregach 5. Wileńskiej Brygady AK, a następnie 3. Brygady Narodowego Zjednoczenia Wojskowego. W 1948 r. kpt. Rajs został stracony na podstawie wyroku, który zapadł w politycznym procesie prowadzonym przed Wojskowym Sądem Rejonowym.
\end{abstract}

Słowa kluczowe: Romuald Rajs „Bury”, Michał Ostapiuk, partyzanci, opór zbrojny, konflikty etniczne.
Abstract: A biography of Captain Romuald Rajs aka Bury by Michał Ostapiuk describes the life of one of the members of the Polish Home Army Wilno (Vilnius) Underground under the German occupation who, after the war, continued military operations in the Białystok Region. Bury fought, first, in the ranks of the Fifth Wilno Brigade of the Home Army, and then in the Third National Military Union Brigade. In 1948, Capt. Rajs was executed after being sentenced to death by a Military District Court.

Keywords: Romuald Rajs aka Bury, Michał Ostapiuk, partisans, armed resistance, ethnic conflicts.

W marcu 2019 r. ukazała się książka Michała Ostapiuka poświęcona postaci kpt. Romualda Rajsa „Burego” (1913-1949). Zacznijmy od krótkiego przedstawienia bohatera biografii: Rajs pochodził z Jabłonnej na Podkarpaciu.

* Michał Ostapiuk, Komendant „Bury”. Biografia kpt. Romualda Adama Rajsa „Burego” (1913-1949), Instytut Pamięci Narodowej - Komisja Ścigania Zbrodni przeciwko Narodowi Polskiemu, Białystok-Olsztyn-Warszawa 2019, ss. $360+112$ wkł. ilustr. 
Wychował się w rodzinie rządcy folwarku. Trudne warunki materialne rodziny zmusiły go do przerwania nauki w Państwowym Gimnazjum im. Królowej Zofii w Sanoku. Dalszą edukację kontynuował w Szkole Podoficerskiej Piechoty dla Małoletnich. Po jej ukończeniu rozpoczął służbę w plutonie konnym 85. Pułku Piechoty w Nowej Wilejce. Od 1939 r. działał w konspiracji na Wileńszczyźnie: w stopniu podporucznika z sukcesami dowodził 1. kompanią szturmową 3. Wileńskiej Brygady Armii Krajowej. Po 1944 r. walczył z formacjami sowieckiego i komunistycznego aparatu represji w odtworzonej na terenie Białostocczyzny 5. Wileńskiej Brygadzie AK dowodzonej przez mjr. Zygmunta Szendzielarza „Łupaszkę”, a po jej czasowym rozwiązaniu we wrześniu 1945 r., został dowódcą 3. Brygady Narodowego Zjednoczenia Wojskowego (NZW) i Pogotowia Akcji Specjalnej (PAS) Komendy Okręgu NZW Białystok. Jesienią 1946 r. zrezygnował z dalszego prowadzenia walki. Mieszkał w Elblągu, następnie w Jeleniej Górze i w Karpaczu. Tam też, 17 listopada 1948 r., po kilkumiesięcznej inwigilacji przez funkcjonariuszy aparatu bezpieczeństwa, został aresztowany i skazany przez Wojskowy Sąd Rejonowy w Białymstoku na karę śmierci. Jego proces $\mathrm{w}$ białostockim kinie Ton miał charakter pokazowy. Wyrok wykonano 30 grudnia $1949 \mathrm{r}$.

Recenzowana biografia dotyka niezwykle trudnego tematu, bowiem na dowodzonej przez kpt. „Burego” 3. Brygadzie NZW ciąży odpowiedzialność za zbrodnie na ludności cywilnej: spalenie pięciu wsi oraz zgładzenie 30 białoruskich furmanów na początku $1946 \mathrm{r}$. w powiecie Bielsk Podlaski. Ogółem w wyniku działań oddziału śmierć poniosło 79 cywilów (w tym kobiety i dzieci). Główny wątek niniejszej recenzji stanowi zaproponowana przez Autora książki „zmiana warstwy interpretacyjnej" wydarzeń, które rozegrały się we wsiach Zaleszany, Wólka Wygonowska, Szpaki, Zanie i Końcowizna na przełomie stycznia i lutego 1946 r. „Okres białostocki” działalności kpt. Rajsa został opisany w książce w rozdziałach piątym i szóstym (s. 135-246).

\section{Bohater bez skazy}

Recenzowana książka jest pierwszą naukową próbą zmierzenia się z życiorysem Romualda Rajsa ${ }^{1}$. Praca składa się z siedmiu rozdziałów i ma układ

${ }^{1}$ Postać kpt. Rajsa jest obecna na kartach opracowań naukowych poświęconych działalności polskiego podziemia zbrojnego w latach II wojny światowej i po $1945 \mathrm{r}$. Zob. K. Krajewski, T. Łabuszewski, „Łupaszka”, „Młot”, „Huzar”. Działalność 5 i 6 Brygady Wileńskiej AK (1944-1952), Warszawa 2002; Z. Kłosiński, 3. Wileńska, Białystok 1995; P. Niwiński, Garnizon Konspiracyjny Miasta Wilna, Toruń 2002; P. Rokicki, Armia Krajowa 
chronologiczno-problemowy. Każda część została poświęcona kolejnym etapom życia i działalności konspiracyjnej kpt. „Burego”. Szósty rozdział w całości dotyczy sprawy „pacyfikacji” białoruskich wsi (s. 176-246). Do książki dołączono bogaty materiał ilustracyjny, w tym niepublikowane wcześniej zdjęcia ze zbiorów prywatnych. Rzeczywiście Ostapiuk włożył sporo pracy w przygotowaną książkę: zebrał pokaźny materiał źródłowy, dotarł do archiwów rodzinnych i relacji oraz przeanalizował kilkutomowe akta śledcze i procesowe kpt. Rajsa oraz szesnastotomowy zbiór dokumentów zebranych w toku postępowania prokuratora Instytutu

na Wileńszczyźnie 1943-1945, Warszawa 2007; K. Krajewski, Na straconych posterunkach. Armia Krajowa na Kresach Wschodnich II Rzeczypospolitej, Kraków 2015; L. Tomaszewski, Wileńszczyzna lat wojny i okupacji 1939-1945, Warszawa 2010; S. Poleszak, Podziemie antykomunistyczne w Łomżyńskiem i Grajewskiem (1944-1947), Warszawa 2004; G. Motyka, Na białych Polaków obława. Wojska NKWD w walce z polskim podziemiem 1944-1953, Kraków 2014; M. Bechta, W.J. Muszyński, Przeciwko Pax Sovietica. Narodowe Zjednoczenie Wojskowe i struktury polityczne ruchu narodowego wobec reżimu komunistycznego 1944-1956, Warszawa 2017; R. Wnuk, Problem bandytyzmu wśród żotnierzy antykomunistycznego podziemia $w$ Polsce (1944-1947), w: Komunizm, ideologia, system, ludzie, red. T. Szarota, Warszawa 2001, s. 67-79; P. Kalisz, P. Łapiński, Polskie podziemie niepodległościowe wobec ludności białoruskiej na Białostocczyźnie po 1944 r. (zarys problematyki), w: Stosunki polsko-białoruskie w województwie białostockim w latach 1939-1956, red. J.J. Milewski, A. Pyżewska, Warszawa 2005. Działania Romualda Rajsa jako dowódcy 3. Brygady NZW stały się tematem książki Jerzego Kułaka: Rozstrzelany oddział. Monografia 3. Wileńskiej Brygady NZW. Białostocczyzna 1945-1946, Białystok 2007, wyd. 2: Rozstrzelany oddział. 3. Wileńska Brygada NZW kapitana Rajsa „Burego”. Białostocczyzna 1945-1946, Warszawa 2015. Ten sam badacz w 2004 r. opublikował biogram Romualda Rajsa (Romuald Adam Rajs (1913-1949), w: Konspiracja i opór społeczny w Polsce 1944-1956. Słownik biograficzny, t. 2, Kraków 2004, s. 432-439). Po 1989 r. pojawiło się także sporo artykułów naukowych, które opisywały działalność 3. Brygady NZW w kontekście popełnionych zbrodni na ludności białoruskiej (np. S. Iwaniuk, Zbrodnie oddziału PAS NZW dowodzonego przez Romualda Rajsa ps. „Bury” popetnione na Białorusinach w styczniu-lutym 1946 r. w dokumentach polskich władz komunistycznych, „Białoruskie Zeszyty Historyczne" 1997, 8, s. 122-180; W. Choruży, Spalenie wsi Zanie przez oddział PAS NZW kpt. Romualda Rajsa „Burego”, „Białoruskie Zeszyty Historyczne” 2002, 18, s. 167-177). Działalność oddziału kpt. „Burego” pojawia się także na kartach najnowszej książki Mariusza Mazura, Antykomunistycznego podziemia portret zbiorowy 1945-1956. Aspekty mentalno-psychologiczne, Lublin 2019, s. 276-278, 337-338, 361-362, 402-403, 412-414 i wcześniejszej pracy Marcina Zaremby, Wielka Trwoga. Polska 1944-1947. Ludowa reakcja na kryzys, Kraków 2012, s. 583. Z kolei Anna Moroz przeanalizowała konflikt polsko-białoruskiej pamięci narosły wokół postaci kpt. Rajsa, A. Moroz, Między pamięcia a historia. Konflikt pamięci zbiorowych Polaków i Białorusinów na przykładzie Romualda Rajsa „Burego”, Warszawa 2016. W ostatnich latach ukazały się także opracowania, których autorzy nadają tym wydarzeniom inną interpretację (zob. K. Krajewski, G. Wąsowski, Kapitan Romuald Rajs „Bury” a Białorusini fakty i mity, „Glaukopis” 2016, 33, s. 93-115. Zob. też: iidem, Kpt. Romuald Rajs „Bury” na kartach ksiązki „Skazy na pancerzach”, czyli prawda według Piotra Zychowicza, http://podziemiezbrojne.blox.pl/resource/Bury_vs_Zychowicz.2018.pdf (dostęp: 4 IV 2019). 
Pamięci Narodowej (IPN) w związku z zakończonym w 2005 r. śledztwem w sprawie działań członków NZW w powiecie bielskim. Cenny, bo oparty na nowych ustaleniach jest wątek związany z ostatnimi latami życia oraz okolicznościami aresztowania Rajsa w 1948 r. Wysiłki te przesłaniają jednak kontrowersje. Książka prowokuje do zadania licznych pytań w sprawie wspomnianej „warstwy interpretacyjnej” działalności 3. Brygady NZW na początku $1946 \mathrm{r}$.

Warto zauważyć, że od pierwszych stron lekturze towarzyszy sugestia o jedynej słusznej interpretacji historii życia i działań Romualda Rajsa. Nie mamy tu do czynienia z klasyczną, naukową biografistyką, która kładzie nacisk na możliwie pełne odtworzenie losów i uczynków bohatera, ale z dziełem zaangażowanym. Już we wstępie Ostapiuk nie ukrywa, że jego praca ma charakter misyjny: Rajs „powinien być uważany za niekwestionowanego bohatera polskiego podziemia. Tak jednak się nie dzieje" (s. 7). Zadaniem postawionym sobie samemu przez Autora książki było „odkłamanie obrazu” bohatera. Obrazu, który został spreparowany przez system komunistyczny, a jego fałszywość została rzekomo utrzymana po 1989 r. i do dziś funkcjonuje w powszechnej opinii.

Z lektury książki dowiadujemy się, że „«Bury» był jednym z wybitnych przedstawicieli generacji, której przyszło walczyć z morderczymi totalitaryzmami” (s. 8); ,,jednym z najdzielniejszych i najefektywniejszych dowódców w polskim ruchu partyzanckim" (s. 324). Czytelnik otrzymuje jednobarwny opis tej postaci: miał posłuch u swoich żołnierzy, był sprawiedliwy, dobrotliwy, rozważny, nie działał pochopnie, cieszył się „,uznaniem miejscowej ludności" (s. 151), dbał, by przy ściąganiu rekwizycji od chłopów na rzecz oddziału „nikogo nadmiernie nie obciążać” (s. 154), zwalczał pospolity bandytyzm (s. 150) itd. Tymczasem, według relacji jego podkomendnych, obok patriotyzmu, odwagi i talentów dowódczych, kapitan miał także wady. Bywał porywczy, impulsywny, mściwy i bezkompromisowy².

Częste podkreślanie przymiotów bohatera wywołuje wrażenie, że Ostapiuk konsekwentnie prowadzi linię obrony - stara się zbudować obraz człowieka bez skazy, kogoś, kto w ogóle nie miał żadnych słabości. Dzieje się tak nie tylko ze stratą dla próby obiektywnej oceny działalności Romualda Rajsa, ale także dla sztuki pisania biografii jako takiej. Nie znajdziemy tu choćby próby głębszej psychologizacji. Wręcz przeciwnie - Autor pospiesznie maskuje wszelkie rysy, które mogłyby

2 P. Niwiński, Czarne karty podziemia poakowskiego. Problemy demoralizacji członków konspiracji niepodległościowej po 1945 r., w: Podziemie zbrojne na Lubelszczyźnie wobec dwóch totalitaryzmów 1939-1956, red. S. Poleszak, A. Puławski, Warszawa 2002, s. 105; J. Bandzo, Tak było. Wspomnienia partyzanta 3. i 5. Wileńskiej Brygady Armii Krajowej, Lublin 2015, s. 168. 
powstać na biograficznym pomniku bohatera książki³. Kapitan Rajs - jak stwierdza - „stał się ofiarą czasów, w jakich żył”, a „jego czyny bronią się same" (s. 324).

W kontekście wątku dotyczącego wydarzeń w powiecie bielskim istotna jest polemika Ostapiuka z wynikami śledztwa S 28/02/Zi prowadzonego przez prokuratora Oddziałowej Komisji Ścigania Zbrodni przeciwko Narodowi Polskiemu IPN w Białymstoku i dotyczącego białoruskich ofiar 3. Brygady NZW ${ }^{4}$. Śledztwo zostało zakończone w 2005 r. uznaniem działań dowodzonej przez „Burego” formacji za czyny należące do „zbrodni ludobójstwa, wchodzącej do kategorii zbrodni przeciwko ludzkości" i zdefiniowanej w Konwencji Organizacji Narodów Zjednoczonych z 9 grudnia 1948 r. Wywód prawny zawarty w ustaleniach końcowych śledztwa opierał się na twierdzeniu, że partyzanci NZW działali z zamiarem wyniszczenia określonej grupy osób, „które łączyła więź oparta na wyznaniu prawosławnym i związanym z tym określaniu przynależności tej grupy osób do narodowości białoruskiej"5. Ostapiuk zdecydowanie odrzuca podstawowe kryterium prawnej definicji ludobójstwa - tezę o religijno-narodowościowych motywach działań podkomendnych kpt. „Burego”. W świetle badań Autora biografii, kontekst „działań pacyfikacyjnych «Burego»" ma tylko i wyłącznie polityczny charakter i wiąże się z czynnym poparciem lokalnej społeczności (w tym ofiar) dla reżimu komunistycznego.

Trudno powstrzymać się już na wstępie przed generalną uwagą, że nawet jeśli działania PAS NZW nie spełniają przesłanek zawartych w prawnej definicji ludobójstwa (ocena taka jest zadaniem prawników), to nie zmienia się podstawowy fakt - ofiarą działalności partyzantów

${ }^{3}$ Przykładem może być opis puczu w 3. Brygadzie AK w grudniu 1943 r., którego głównym wykonawcą był służący w tym oddziale ppor. Romuald Rajs „Bury”. Ostapiuk łatwo przechodzi nad tym wydarzeniem do porządku dziennego, tłumacząc wywołany przez żołnierza bunt „próbą obrony swojego dowódcy” (s. 76). Tymczasem zainspirowanie buntu, aresztowanie przedstawicieli Komendy Okręgu Wilno AK, improwizowane skazanie ich na rozstrzelanie (zamienione na wybatożenie) i wykonanie „wyroku” osobiście przez „Burego” zasługuje na krytyczną ocenę. Nawet jeśli można zgodzić się z tezą, że niewyciągnięcie konsekwencji wobec buntowników świadczyło o słabości komendanta Okręgu, ppłk. Aleksandra Krzyżanowskiego „Wilka”, nie tłumaczy to jednak niesubordynacji Rajsa (jak dosadnie napisał dr Kazimierz Krajewski: „w Nowogródzkim Okręgu AK winni takiego wykroczenia skazani przez sąd polowy skończyliby z kulą w głowie pod pierwszą z brzegu stodołą", cyt. za: K. Krajewski, Na straconych posterunkach, s. 391).

${ }^{4}$ https://ipn.gov.pl/pl/dla-mediow/komunikaty/67471,Komunikat-dotyczacy-informacji-zawartych-w-ustaleniach-koncowych-sledztwa-S-2802.html?search=37218140452 (dostęp: 4 IV 2019).

${ }^{5}$ https://ipn.gov.pl/pl/dla-mediow/komunikaty/9989,Informacja-o-ustaleniachkoncowych-sledztwa-S-2802Zi-w-sprawie-pozbawienia-zycia.html (dostęp: 4 IV 2019). 
była ludność cywilna. Na gruncie prawnym podobne przypadki są analizowane w oparciu o kategorię zbrodni przeciwko ludzkości rozumianej zgodnie z treścią art. 7 Statutu Międzynarodowego Trybunału Karnego. Autor książki, choć postanowił wejść w polemikę z interpretacjami prawnymi, jednocześnie nie zauważył chyba tego faktu.

\section{Podziemie narodowe}

W niezwykle oszczędny sposób w książce został przedstawiony wątek podziemia narodowego. A przecież w momencie „pacyfikacji białoruskich wiosek" kpt. Rajs reprezentował ramię zbrojne konkretnego nurtu politycznego - Stronnictwa Narodowego (SN). Tymczasem czytelnik może wywnioskować, że NZW był naturalną alternatywą dla żołnierzy, którzy tak jak „Bury” nie godzili się z demobilizacją przeprowadzaną po deklaracji płk. Jana Mazurkiewicza „Radosława” wczesną jesienią 1945 r., równolegle ze zmianami organizacyjnymi poakowskiego podziemia (tzw. akcja rozładowywania lasów). Powstałe wówczas Zrzeszenie Wolność i Niezawisłość (WiN) kładło nacisk na konspirację cywilną. Bezkompromisowe wobec komunistów i tzw. legalnej opozycji podziemie narodowe od jesieni 1944 r. rywalizowało z AK na terenie Białostocczyzny o wpływy. Demobilizację uznano w kierownictwie NZW za zdradę i postulowano, aby ujawniających się żołnierzy oddać pod sąd polowy. Część żołnierzy z poakowskich szeregów przyjmowano do narodowych oddziałów zbrojnych. W tych okolicznościach Romuald Rajs został dowódcą 3. Brygady NZW.

$\mathrm{Na}$ kartach książki, jak w antycznej tragedii, losem „Burego” często rządzi „zaistniała sytuacja”. Również jego przejście do NZW wynika ze splotu okoliczności. Autor pisze, że „Bury” pozostał wierny środowisku i tradycji akowskiej, a jesienią 1945 r. tylko „zmienił organizację" (s. 162) ${ }^{6}$. Bardziej dociekliwi czytelnicy otrzymują więc sugestię, że kpt. Rajs nie kierował się poglądami nowej organizacji, a jedynie gotowością do dalszej walki z aparatem komunistycznym. Być może Autor doszedł do wniosku, że taki zabieg zwalnia go z pogłębionego opisu ideowej strony działalności NZW - przecież „Bury” i inni żołnierze mający za sobą szlak bojowy AK nie byli uformowanymi narodowcami. Zapewne jednak akceptowali założenia programowe, które przyświecały nowo

${ }^{6}$ Niejako na potwierdzenie tej tezy w przypisie zacytowane zostało „źródłowe echo” - podczas przesłuchania przez UB ppłk Antoni Olechnowicz „Pohorecki” zeznał, że były dowódca Rajsa, por. Gracjan Fróg: „nie wierzy, aby «Bury» stał się ideowym wyznawcą NSZ [Narodowych Sił Zbrojnych]" (s. 162). 
wybranej formacji. Do NZW nie przyjmowano każdego: „Wchłaniamy tylko element narodowy lub o mocnym kośćcu moralnym. Dla sanacyjnych wichrzycieli nie ma tu miejsca"7 - pisano we wrześniu 1945 r. na łamach konspiracyjnej „Walki”.

Jak przyznaje Ostapiuk, przyłączenie się „Burego” do NZW zostało źle odebrane wśród akowców. Zapewne jednym z powodów była rozbieżność w podejściu do ogłoszonej przez władze 2 sierpnia 1945 r. amnestii. Czy jednak tylko to? Dowódca Rajsa, mjr Zygmunt Szendzielarz „Łupaszka” również negatywnie odniósł się do samego pomysłu demobilizacji, jednak wybrał inną drogę dla dalszej działalności. Nakazał podległym dowódcom szwadronów rozformowanie oddziału, po czym przeniósł się na nowy teren. Porucznik „Bury” nie wykonał tego rozkazu, tylko wraz ze swoim szwadronem przeszedł pod komendę organizacji będącej w tamtym czasie w konflikcie ze strukturami poakowskiego podziemia.

W dobie postępującej uniwersalizacji konspiracji antykomunistycznej pod terminem „Żołnierze Wyklęci” coraz częściej zapominamy, że różne nurty podziemia łączyła walka z komunistami, ale różniły kwestie ideowe i programowe. Już w treści rozkazu nr 1639 z 15 września 1945 r. o przyjęciu części 3. Brygady Wileńskiej w struktury NZW znajdują się odwołania do dorobku ideowego konkretnego nurtu politycznego. Oto wileńscy żołnierze stali się częścią siły zbrojnej walczącej w imię budowy „Wielkiej, Wolnej, Sprawiedliwej, Katolickiej Polski Narodowej”, a postawione przed nimi zadania miały wypełnić ",testament Duchowego Wodza Narodu Polskiego Romana Dmowskiego". Rozkaz kończył się słowami: „wierzę, że obowiązek spoczywający na naszych barkach odbudowy Wolnej Polski Narodowej i wcielenie w życie hasła Polska dla Polaka popchnie nas do dalszego wysiłku, oddania z siebie wszystkiego co polskie, wyrobi w nas karność żołnierską"8.

Czy ma to w ogóle znaczenie dla nakreślenia postaci bohatera? Nawet jeśli przyjmiemy, że on sam w ogóle nie interesował się ideową stroną działalności NZW, to na pewno aktualne jest pytanie, na ile poglądy endecji na sprawy mniejszości narodowych odgrywały rolę w postrzeganiu przez dowództwo NZW „skomunizowanej” ludności białoruskiej. Niestety wątek ten nie znalazł miejsca na kartach recenzowanej książki.

Co prawda, gdy czytelnik zdąży już zapoznać się z całą gamą antypolskich postaw miejscowych Białorusinów, Autor podejmuje pewną próbę wyjaśnienia, czym dla NZW było hasło „Polska dla Polaków”. Czyni to

7 AIPN Bi 212/2997/7, „Walka” 1945, 33, k. 157.

${ }^{8}$ AIPN Bi 212/2997, t. 7, Rozkaz nr 1639 o przyjęciu 3 Brygady Wileńskiej do Narodowego Zjednoczenia Wojskowego, 15 IX 1945, k. 5. 
jednak w sposób wyjątkowo pokrętny, posiłkując się dwoma krótkimi cytatami: z Adama Doboszyńskiego (,Hasło to wysunęła i urzeczywistniła $\mathrm{u}$ nas dopiero agentura sowiecka, nie znajdziemy go $\mathrm{u}$ żadnego z polskich myślicieli", s. 193) oraz wyimkiem z endeckiej gazetki konspiracyjnej z 1948 r., że z reżimem komunistycznym walczą Polacy bez względu m.in. na pochodzenie i wyznanie. Autor nie pokusił się więc o szersze (i bezpośrednie) odwołania do literatury przedmiotu czy choćby publicystyki SN dotyczącej stosunku do Białorusinów lub też szerzej - do mniejszości narodowych. Sprawy nie załatwia przekonanie, że „program polityczny, o który walczyło NZW, nie zakładał «czyszczenia» ziem polskich z mniejszości narodowych - zakładano polonizację ich przedstawicieli" (s. 193). Ale cóż to zdanie oznaczało w praktyce?

Apologeci ruchu narodowego podkreślają, że teoretycy endeccy nigdy nie nawoływali do wypędzania czy jakichkolwiek innych represji wobec ludności niepolskiej. Wręcz przeciwnie - mniejszości narodowe wzbogacały w ich opinii Polskę, ale działo się tak dopóty, dopóki spełniały podstawowy warunek: reprezentowały lojalny stosunek do państwa polskiego. Tymczasem wzrastająca od schyłku XIX w. wśród Ukraińców, Białorusinów czy Litwinów świadomość narodowa, oparta na kryterium etnicznym, kładła się cieniem na tym warunku.

W często przywoływanym w biografii zbiorze Żeby Polska była polska bez trudu odnajdziemy bardziej obrazowe cytaty dotyczące postrzegania przez obóz narodowy kwestii mniejszości, niż te, które wybrał Ostapiuk. W 1940 r. w broszurze przedstawiającej podstawowe założenia programowe SN pisano m.in.:

Polityka nasza w stosunku do mniejszości narodowych będzie jasna i prosta: mniejszości napływowe, o ile nie zasymilują się u nas, nie mają po co tu siedzieć, będziemy się starali ich pozbyć, a już kategorycznie - Niemców i Żydów. Tych ostatnich usuniemy zupełnie radykalnie. Gdzie? To już ich głowa. Byle ich nie było u nas. W stosunku do mniejszości osiadłych, jak Białorusinów i Rusinów, czyli tak zwanych Ukraińców, będziemy prowadzić politykę asymilacyjną, traktując ich jako szczepy pokrewne, nie zaś równorzędne narody, bo takimi, rzecz jasna, nie są .

Warto zauważyć, że zgodnie z wykładnią SN odrębność narodowa Białorusinów (podobnie jak Ukraińców) była sztucznym wytworem

${ }^{9}$ Broszura przedstawiająca podstawowe założenia programowe SN oraz opisujacca pożądane cechy narodowca i skuteczne metody jego działania, 1940 r., w: „Żeby Polska była polska!” Antologia publicystyki konspiracyjnej podziemia narodowego 1939-1950, wstęp, wybór i oprac. M.J. Chodakiewicz, W.J. Muszyński, Warszawa 2010, s. 821. 
zaborczych mocarstw, a jakiekolwiek równouprawnienie - jak pisano w 1945 r. - byłoby tylko „pozwoleniem na kontynuowanie obcej polityki wewnątrz narodu polskiego" 10 . W ocenie endecji mniejszości narodowe były czynnikiem destabilizującym państwo polskie. Antidotum miało być maksymalne ograniczenie kultywowania przez nie odrębności narodowej, ponieważ różne tego formy mogły podsycać separatystyczną irredentę. W publicystyce endeckiej m.in. odmawiano mniejszościom prawa do nauczania własnego języka w szkołach ${ }^{11}$, a ,jednym z głównych zadań Kościoła w Polsce” miało być „nawracanie prawosławnych”12 (w opinii endecji byli to potomkowie Polaków, którzy za caratu zostali zmuszeni do konwersji na prawosławie).

Na pierwszy rzut oka może się wydawać, że są to chybione wywody, bo przecież w recenzowanej książce sprawa postrzegania Białorusinów przez NZW zasadza się nie na kwestiach narodowości czy wyznania, a jedynie na ich sprzyjaniu komunistom. W dodatku sam bohater książki w podejściu do ludności białoruskiej nie kieruje się w ogóle poglądami jakiegokolwiek nurtu politycznego czy uprzedzeniami, a jedynie chęcią walki z komunistami. Autor wielokrotnie uwypukla podobne sformułowania, tak jakby przez całą książkę prowadził narrację polemiczną z wynikami śledztwa prokuratora IPN, mając do dyspozycji tylko słownikową definicję pojęcia ludobójstwa. Jest to ślepa uliczka. Ta „strategia" zakłada bowiem, że należy bezwzględnie odrzucić czynnik etniczny w postrzeganiu białoruskich mieszkańców Białostocczyzny przez żołnierzy podziemia. Przecież tak samo zwalczani byli i Polacy, którzy kolaborowali z reżimem. Jednak, abstrahując zupełnie od wyników śledztwa prokuratora IPN, zadajmy jeszcze raz pytanie: czy czynnik etniczny nie występuje tutaj w parze z kwestiami światopoglądowymi? Dlaczego tylko w stosunku do Białorusinów zostaje zastosowana odpowiedzialność zbiorowa i kierowane są groźby zmierzające do usunięcia ich z terenów Białostocczyzny? Dlaczego tylko Białorusinów sprzyjających komunistom, a więc reprezentujących „nielojalny stosunek do Polski” (s. 189), podziemie narodowe wzywa do wyjazdu do ZSRR, a nie nawołuje do jakiejś formy zbiorowej odpowiedzialności w stosunku do komunistów Polaków? Mniejszość białoruska po $1944 \mathrm{r}$. była postrzegana en masse przez konspirację narodową jako „element wrogi” i podatny na obce wpływy (ideologię komunistyczną). Jednym z postulatów pojawiających się w kręgach dowódczych NZW było zmuszenie ludności białoruskiej

\footnotetext{
10 Założenia programowe Stronnictwa Narodowego, 1945 r., w: ibidem, s. 971.

11 Ibidem, s. 994

12 Ibidem, s. 995.
} 
(postrzeganej jako „skomunizowana”) do poddania się tzw. repatriacji na teren Białoruskiej Socjalistycznej Republiki Radzieckiej ${ }^{13}$. Podczas procesu pokazowego kpt. „Bury” powiedział, że dowództwo NZW wydało rozkaz spalenia wsi, ponieważ miejscowa ludność posiadała broń, źle odnosiła się do „członków nielegalnych organizacji” oraz „zasadniczo biorąc na podstawę fakt, że [--] nie repatriowała się do Związku Radzieckiego"14.

Autor przyznaje, że spore poparcie ze strony Białorusinów dla Komunistycznej Partii Zachodniej Białorusi (KPZB) w okresie międzywojennym stworzyło „dalece szkodliwy stereotyp: Białorusin-komunista” (s. 182). Gdy dodamy do tego fakt, że w optyce obozu narodowego mniejszości narodowe ze względu na „uleganie wpływom antypolskich ideologii” stanowiły potencjalne zagrożenie, wątpliwości co do kategorycznego oddzielania narodowości/wyznania od postaw i poglądów robią się jeszcze większe. To tak, jakby uznać, że cały, pokaźny dorobek nurtu narodowego na temat Żydów opierał się jedynie na twierdzeniu, że np. utożsamiano ich z komunizmem, nie stosując przy tym etnicznych uogólnień. Tymczasem, gdy w 1945 r. teoretycy SN piszą, że „Żydzi nigdy nie kierowali się dobrem Polski, a w ciągu jej historii działali zawsze na jej szkodę"15, nie zadają sobie trudu, by sprawę w jakikolwiek sposób niuansować. Również spory odsetek komunizujących Białorusinów na Białostocczyźnie był potwierdzeniem tezy SN o mniejszościach narodowych jako „rozsadniku” państwa. Ostapiuk zresztą przyznaje, że sam kpt. Rajs „negatywnie oceniał zachowanie mniejszości narodowych w stosunku do państwa polskiego" (s. 194) ${ }^{16}$.

Niewątpliwie trudno oddzielić sympatie polityczne mieszkańców białoruskich wsi od kryterium narodowościowego. Na postawę polskiego podziemia wobec Białorusinów złożyło się zresztą wiele uwarunkowań, nie tylko podejście do komunistycznej władzy. Partyzanci pochodzący z Kresów mieli swój świeży bagaż doświadczeń z kolaborantami białoruskimi, litewskimi czy ukraińskimi. Brutalizacji postaw wobec mniejszości mogły sprzyjać różne doświadczenia ostatnich kilku lat krwawej wojny, w tym m.in. rzezie dokonane przez Organizację Ukraińskich Nacjonalistów (OUN) i Ukraińską Powstańczą Armię (UPA), które miały miejsce

13 AIPN Bi 212/2997, t. 1, Dodatkowe zeznania względnie sprostowania do akt śledztwa Romualda Rajsa, 11 III 1949, k. 342. Zamiary NZW w tym względzie potwierdził także m.in. por. Jan Trusiak „Korycki”, komendant Obwodu WiN Bielsk Podlaski. M. Bechta, W.J. Muszyński, op. cit., s. 267.

14 AIPN Bi 212/2997, t. 5, Protokół rozprawy głównej Wojskowy Sąd Rejonowy w Białymstoku przeciwko Romualdowi Rajsowi, 19 IX 1949, k. 63.

15 „Żeby Polska była polska!”, s. 972.

${ }^{16}$ Zob. też: P. Kalisz, P. Łapiński, op. cit., s. 96; G. Motyka, op. cit., s. 283. 
na Wołyniu i w Galicji Wschodniej, i które zdeterminowały dynamikę działań polskiego podziemia na Lubelszczyźnie ${ }^{17}$.

W protokołach przesłuchań członków NZW sporządzonych podczas śledztw Urzędu Bezpieczeństwa (UB) w końcu lat czterdziestych XX w. możemy odnaleźć różne powody pacyfikacji białoruskich wsi - głównie te o charakterze politycznym: złe odnoszenie się do oddziałów NZW, współpraca Białorusinów z Niemcami podczas wojny, poparcie dla komunistów itp. Niekiedy w parze pojawiają się także wątki etniczne. Jeden z partyzantów PAS NZW, Jerzy Puławski „Gołąb” zeznał, że: „Wsie były palone według oświadczenia «Burego» dlatego, że ludność tamtejszych wsi była nieprzychylnie ustosunkowana do jego oddziału, dawała informacje władzom BP [Bezpieczeństwa Publicznego] o przemarszach oddziałów leśnych i z powodu przynależności jej do ludności białoruskiej"18. Inny Marian Maliszewski „Wyrwa” - miał powiedzieć: „Wsie zostały spalone, iż byli narodowości białoruskiej, a «Bury» i «Rekin» byli nacjonalistycznie ustosunkowani: przeciw nim walczyli" ${ }^{19}$. $Z$ kolei w jednym $z$ donosów informator celny „Jerzy” (Lucjan Sikorski „Mucha”, były członek NZW) przedstawił przebieg rozmowy z Romualdem Rajsem, w toku której kapitan powiedział odnośnie do spacyfikowanych wiosek, że „on ich spalił na własną rękę dlatego, że to były wioski bardzo niebezpieczne dla partyzantów i dla nich tu nie ma miejsca w Polsce, że oni mogą sobie wyjechać do Rosji, bo w Polsce jest mało miejsca dla Polaków i Ukraińców [zapewne chodzi o Białorusinów - przyp. M.S.] tu nie potrzeba, bo Polska tylko dla Polaków"20. Według Ostapiuka podobne zeznania i donosy były wynikiem manipulacji „ubeków”. Wskazują na to poszlaki związane m.in. z niskimi wyrokami, jakie otrzymali członkowie NZW, którzy współpracowali podczas śledztwa z funkcjonariuszami śledczymi. Jednak w taki sposób można zakwestionować lub dowolnie interpretować każdą relację zawartą w aktach proweniencji UB.

17 Mariusz Zajączkowski wspomina w swojej książce o lubelskim epizodzie działalności 3. Brygady NZW wiosną 1946 r., gdy partyzanci pod dowództwem por. Kazimierza Chmielowskiego „Rekina” operowali m.in. w okolicach Siedlec i Janowa Podlaskiego. Na miejscu mieli kolportować ulotki nawołujące do odwetu na Ukraińcach za rzezie na Wołyniu. M. Zajączkowski, Pod znakiem króla Daniela. OUN-B i UPA na Lubelszczyźnie 1944-1950, Lublin-Warszawa 2016, s. 186-187.

${ }^{18}$ AIPN Bi 212/2997, t. 4, Protokół przesłuchania Jerzego Puławskiego z 9 VIII 1949, k. 59.

19 AIPN Bi 212/2997, t. 3, Protokół przesłuchania Mariana Maliszewskiego z 18 VII 1949, k. 239.

${ }^{20}$ Informacja o ustaleniach końcowych śledztwa S 28/02/Zi w sprawie pozbawienia życia 79 osób - mieszkańców powiatu Bielsk Podlaski w tym 30 osób tzw. furmanów w lesie koło Puchał Starych, dokonanych w okresie od dnia 29 stycznia 1946 r. do dnia 2 lutego 1946 r., za: https://ipn.gov.pl/pl/dla-mediow/komunikaty/9989,Informacja-o-ustaleniach-koncowych-sledztwa-S-2802Zi-w-sprawie-pozbawienia-zycia.html (dostęp: 9 IV 2019). 
Zwłaszcza jeśli ma się ona stać tłem dla konkretnej tezy - w tym przypadku, że za „etniczno-wyznaniowymi” motywami działań kpt. Rajsa stoi komunistyczny aparat represji. Wobec takiej pozaźródłowej (ale pozycjonującej każdego ewentualnego polemistę jako obrońcę ubeckiej narracji) argumentacji jest się bezsilnym i Autor zdaje sobie chyba z tego sprawę.

\section{Komunizujące wsie}

Zasadnicza część książki została poświęcona rekonstrukcji wydarzeń, które miały miejsce na przełomie stycznia i lutego $1946 \mathrm{r}$. we wsiach: Zaleszany, Wólka Wygonowska, Zanie, Szpaki oraz Końcowizna. Autor sporo miejsca poświęcił nakreśleniu ich tła. Stanowi je wątek dotyczący silnego „skomunizowania” części miejscowej ludności. Czytelnicy mogą dowiedzieć się, że „Białorusini od lat dwudziestych tworzyli antypolskie struktury" (s. 183). Dotyczyło to przede wszystkim mieszkańców powiatu bielskiego, którzy przed wojną sympatyzowali m.in. z KPZB. Dalej Autor opisuje antypolskie wystąpienia i mordy urządzane przez część Białorusinów w 1939 r., wspomina o „gorących powitaniach, jakie ludność białoruska zgotowała Armii Czerwonej" (s. 186) oraz wsparciu udzielonym sowieckiej administracji okupacyjnej. Z przytoczonych w książce danych wynika, że Białorusini przeważali po wojnie w strukturach miejscowej Polskiej Partii Robotniczej (PPR) i Urzędów Bezpieczeństwa Publicznego (UBP). Ostapiuk niekiedy stara się unikać generalizacji. Kilkukrotnie podkreśla, że problem nie dotyczył wszystkich Białorusinów. Nie jest w tym jednak konsekwentny, bo już w przypadku pięciu miejscowości, które stały się celem ataku partyzantów kpt. „Burego”, pisze po prostu o „silnie skomunizowanych wsiach" (s. 195).

Próba przybliżenia stosunków polsko-białoruskich w rozdziałach książki, które dotyczą „pacyfikacji”, została przeprowadzona pobieżnie. Cały kontekst skomplikowanej sytuacji na Białostocczyźnie po $1944 \mathrm{r}$. został skoncentrowany na walce niepodległościowego podziemia zbrojnego z komunistami i ich poplecznikami. Walki, w której co prawda racje są oczywiste, ale każda „zlikwidowana” cywilna ofiara jest automatycznie zapisywana po stronie zwolenników wprowadzanego na sowieckich bagnetach systemu. W tak zaproponowanej wizji o wiele łatwiej przychodzi rozgrzeszenie partyzantów z popełnionych czynów. „[Rajs] zmuszony był toczyć krwawą walkę z reżimami, w której niewiele było miejsca na rycerskość" (s. 324) - pisze Ostapiuk w zakończeniu książki.

$\mathrm{W}$ pracy pominięto wątek postrzegania problemu białoruskiego przez władze komunistyczne, a jest to o tyle istotne, że przynależność 
państwowa tych terenów nie była na początku oczywista. Jakie znaczenie miała zarządzona przez Sowietów na podstawie tzw. umów republikańskich akcja repatriacyjna ludności prawosławnej na terytorium Białoruskiej SRR? W literaturze przedmiotu często można spotkać się ze stwierdzeniem, że opowiedzenie się po stronie komunistów i lojalność wobec władz dawały tej ludności „szansę na pozostanie na swojej ziemi"21. Autor nie odnosi się do tzw. dobrowolnej akcji repatriacyjnej, a przecież miała ona znaczenie także dla działań polskiego podziemia.

Czytelnik otrzymuje dane o zaangażowaniu mniejszości białoruskiej po stronie komunistów, ale nie dowiaduje się, jakie mogły być źródła tych postaw. Dlaczego popularnością cieszył się wśród jej przedstawicieli komunizm? Czy wynikało to np. z przyczyn ekonomicznych, politycznych, społecznych, pragmatycznych? Czy Białorusini wysuwali własne żądania o charakterze narodowym? Wreszcie - dlaczego chłopi białoruscy nie mieli powodów, by wspierać masowo polską konspirację? Częściowo Ostapiuk odpowiada na te pytanie, wskazując choćby na napięte relacje polsko-białoruskie podczas okupacji, a także na „dość brutalny charakter” rekwizycji żywności przeprowadzanych w białoruskich wsiach przez polskich partyzantów. Spieszy jednak z wyjaśnieniem, że taka brutalność nie powinna dziwić: „Pamiętajmy, że żołnierze podziemia żyli w ciągłym poczuciu zagrożenia życia ze strony komunistycznego reżimu, co musiało odbijać się na stosunku do ludności, którą - czasem niesłusznie - uznawano za sprzyjającą okupantowi" (s. 192). Zdanie to kusi, aby uzupełnić je o obraz à rebours: również miejscowa ludność białoruska żyła w ciągłym zagrożeniu z powodu uciążliwych rekwizycji żołnierzy podziemia, których - czasami niesłusznie - uznawano za wrogich Białorusinom. W pracy Ostapiuka takich prób zobiektywizowania opisywanej sytuacji, a więc wyjścia poza narrację kreśloną z pozycji bohatera i jego środowiska, niestety brakuje.

\section{Opis pacyfikacji Zaleszan, Wólki Wygonowskiej, Szpaków, Zań i Końcowizny}

Jak już wspomniano, na przełomie stycznia i lutego 1946 r. celem akcji 3. Brygady NZW stały się wsie zamieszkałe przez ludność białoruską. Prawdopodobnie kpt. Rajs przystąpił wówczas do realizacji odłożonego

${ }^{21}$ E. Mironowicz, Polityka władz polskich wobec Białorusinów. Stosunek ludności białoruskiej do państwa polskiego (1944-1956), w: Stosunki polsko-białoruskie, s. 73. Szerzej: idem, Białorusini w Polsce 1944-1949, Warszawa 1993; E. Mironowicz, S. Tokć, R. Radzik, Zmiana struktury narodowościowej na pograniczu polsko-białoruskim w XX wieku, Białystok 2005. 
uprzednio w czasie rozkazu mjr. Floriana Lewickiego „Kotwicza” z 20 września 1945 r., dotyczącego „spacyfikowania skomunizowanej ludności zamieszkującej tereny powiatu bielskiego" (s. 177). Rozkaz ten dotyczył zwalczania „wrogich jednostek UBP [--] agend UBP (szpicle), zorganizowania odwetu na wrogiej ludności do sprawy konspiracyjnej"22. Autor, nie powołując się na żadne posiłkowe źródła, interpretuje ten dokument następująco: „oddziały PAS miały za zadanie wyłuskać osoby aktywnie współpracujące z reżimem komunistycznym i je zlikwidować, ludność podejrzana o wspieranie władzy ludowej miała zaś zostać ukarana materialnie". Istotne, że dokument wskazywał na zastosowanie odpowiedzialności zbiorowej wobec cywilnych mieszkańców wsi uważanych za skomunizowane.

Intencją partyzantów było: a) ukaranie „szpicli” (przeprowadzenie egzekucji prawdopodobnie na podstawie wcześniejszego wywiadu lub informacji uzyskanych na miejscu); b) ukaranie i przestrzeżenie ogółu ludności przed angażowaniem się po stronie reżimu; c) przynajmniej w kilku przypadkach zmuszenie białoruskich chłopów do opuszczenia swoich miejscowości. Proces decyzyjny towarzyszący spaleniu pięciu miejscowości jest jednak niejasny. Nie wiadomo z całą pewnością, czy 3. Brygada NZW realizowała rozkaz mjr. „Kotwicza”, czy działania te wynikały z samodzielnej decyzji kpt. „Burego”. W biografii możemy przeczytać, że spalenie Zaleszan i Wólki Wygonowskiej oraz egzekucja furmanów były prawdopodobnie wynikiem decyzji podjętej samodzielnie przez dowódcę oddziału. Autor twierdzi, że kara wymierzona w ludność miała mieć jedynie wymiar „materialny”, jednak sam przywołuje w książce informację o stawianiu przez dowództwo NZW ultimatum dotyczącego trwałego opuszczenia domostw białoruskim mieszkańcom wsi Szpaki i Zanie. Czyny te zaświadczają, że członkowie NZW nie działali „punktowo" - ich celem nie byli jedynie konkretni, wyróżniający się działacze PPR czy osoby zagrażające bezpośrednio podziemiu, ale - w ramach zastosowania zasady odpowiedzialności zbiorowej - cała białoruska ludność danej miejscowości. Jeszcze raz należy powtórzyć: wezwania do wyjazdu na wschód ze strony podziemia były adresowane do Białorusinów (a więc oparte o kryterium etniczne, choć główny zarzut dotyczył poparcia dla reżimu komunistycznego) ${ }^{23}$. Intencji sprawców nie zmienia twierdzenie

${ }^{22}$ AIPN Bi 212/2997, t. 7, Kopia rozkazu mjr. Floriana Lewickiego „Kotwicza” z 20 IX 1945, k. 7.

${ }^{23}$ Ta strona działalności podziemia narodowego stała się dla prokuratora IPN w 2005 r. podstawą do zakwalifikowania czynów 3. Brygady NZW jako noszących znamiona czystki etnicznej („masowe usuwanie lub wypędzanie osób z ich domów, jawne naruszanie praw tych osób w celu przemieszczenia lub zniszczenia grup narodowych, etnicznych, rasowych lub religijnych"). 
Autora książki dodane przy okazji opisu pacyfikacji wsi Szpaki, że nikt nie egzekwował następnie postawionego ultimatum (s. 231). Brzmi ono zresztą lekkomyślnie, a wręcz niedorzecznie - bo oto oddział wkracza do wsi, pali ją, zabija kilku mieszkańców i zostawia podobne wezwanie, a sterroryzowana ludność ma nie traktować go poważnie?

Autor sugeruje, że działania 3. Brygady NZW (palenie wsi oraz pozbawienie majątku kolaborantów) były charakterystycznymi metodami dla działalności polskiego podziemia zbrojnego po wojnie (s. 188). Tezę tę ma potwierdzać przywołanie w przypisie przykładu spalenia 4 grudnia 1946 r. przez oddział Zrzeszenia WiN pod dowództwem kpt. Zdzisława Brońskiego „Uskoka” wsi Rozkopaczew (pow. lubartowski). Tyle że konkretnym celem ludzi kpt. „Uskoka” było kilkudziesięciu uzbrojonych ormowców z tej wsi. Jak pisał w swoim pamiętniku: „Na zlecenie swoich władz, szubrawcy ci plądrowali ciągle teren i maltretowali ludność. Zdarzały się nawet wypadki samowolnych zabójstw [--]. Ze wszech stron zwracano się do partyzantów z prośbą, by zniszczyli tę plagę"24. $\mathrm{Z}$ dalszej lektury pamiętnika przebija dylemat związany z podpaleniem wsi, przed jakim stanął dowodzący akcją „Uskok” („Chcąc znów uniknąć niszczenia wsi pożarem - zadanie było nie do wykonania, bo siedzący w zabudowaniach ormowcy, choćby nawet tchórze, będą mieli zawsze przewagę nad nami - podchodzącymi z pola"25). Partyzanci z połączonych oddziałów „Uskoka”, „Jastrzębia” i „Ordona” weszli tyralierą do wsi i zostali ostrzelani krótką serią przez uciekających ormowców. W wyniku strzałów oddanych przez „winowców” w kierunku zabudowań powstał pożar. Patrolując pospiesznie Rozkopaczew, partyzanci szukali konkretnych osób, gdy ich nie znaleźli zarządzono odwrót, jak twierdził „Uskok”: „nie chcąc przeszkadzać w gaszeniu pożaru”26 (w jego wyniku spłonęło 26 budynków). Podczas tej akcji zginął jeden członek Ochotniczej Rezerwy Milicji Obywatelskiej. Sam kpt. Broński podkreślał, że obyło się bez ofiar wśród przypadkowych cywilów. Różnice pomiędzy pacyfikacją wsi na Lubelszczyźnie przeprowadzoną przez oddział WiN i działaniami 3. Brygady NZW w Białostockiem widać więc gołym okiem. Partyzanci NZW traktowali spalenie wsi jako sposób na ukaranie ogółu miejscowej ludności.

Sporo pytań i wątpliwości nasuwa się po przeczytaniu rekonstrukcji zdarzeń w pięciu miejscowościach powiatu bielskiego. Autor polemizuje

${ }^{24}$ Z. Broński, Pamiętnik (wrzesień 1939 - maj 1949), wstęp i oprac. S. Poleszak, LublinWarszawa 2015, s. 213.

${ }^{25}$ Ibidem, s. 213.

${ }^{26}$ Ibidem, s. 214. 
m.in. z pracą Jerzego Kułaka ${ }^{27}$, jednak zaproponowana przez niego narracja nie zmienia znacząco utrwalonych w literaturze informacji o tym, co stało się na przełomie stycznia i lutego $1946 \mathrm{r}$. Zmienia się za to interpretacja tych wydarzeń. Wart dodać, że zarówno argumentacja, jak i cytowania źródłowe Autora w wielu miejscach nie są nowatorskie, a korespondują (a nawet są $\mathrm{w}$ dużej mierze powtórzeniami) z ustaleniami Kazimierza Krajewskiego i Grzegorza Wąsowskiego zawartymi w artykule, który ukazał się w 2016 r. na łamach czasopisma "Glaukopis”28.

W recenzowanej biografii przebieg wydarzeń w powiecie bielskim został przedstawiony następująco: 29 stycznia 1946 r. oddział kpt. Rajsa „Burego” wszedł do „wybitnie skomunizowanej” (s. 195) wsi Zaleszany, pozorując 9. Pułk Korpusu Bezpieczeństwa Wewnętrznego (KBW). „Mieszkańcy nie wiedzieli kim naprawdę są żołnierze”, a „początkowo Bury nie miał wrogich zamiarów wobec Zaleszan". Dowódca zmienił zdanie, gdy mieszkańcy zaczęli okazywać żołnierzom pozorowanego oddziału lekceważenie i ociągali się z wykonywaniem rozkazów. Ta postawa miała wynikać $\mathrm{z}$ faktu, że wieś była mocno powiązana z Sowietami i „zasłużona dla systemu komunistycznego”, stąd jej mieszkańcy nie czuli się w obowiązku dostarczenia uciążliwych podwód i pozwalali sobie na demonstrowanie negatywnego stosunku do „noszących polskie mundury" żołnierzy KBW (choć dowodzonych przez udających sowieckich oficerów „Burego” i jego zastępcę). Trzeba przyznać, że jest to dość skomplikowana konstrukcja logiczna.

Partyzanci postanowili ukarać śmiercią zidentyfikowanych komunistycznych aktywistów w Zaleszanach, a wieś spalić. Aby „uniknąć niezamierzonych ofiar" (s. 204) zarządzili, aby wszyscy mieszkańcy stawili się w chacie Grzegorza Sacharczuka. Do grupy aktywistów, a więc osób, co do których - w mniemaniu członków NZW - słuszność wymierzenia im najwyższej kary nie ulegała wątpliwości, Autor zaliczył Fiodora Sacharczuka (o którym Kułak napisał, że został zabity tuż po wkroczeniu oddziału do wsi za odmowę wydania żołnierzom owsa) oraz dwóch członków PPR - szesnastoletniego syna sołtysa Piotra Demianiuka ${ }^{29}$ i wylegitymowanego przez partyzantów sekretarza partii komunistycznej z sąsiedniej wsi, Aleksandra Zielinkę. Brakuje jasnego wskazania źródła, z którego wynikałoby, na jakiej podstawie (i czy w ogóle) Fiodor Sacharczuk został wskazany/zidentyfikowany przez partyzantów jako

27 J. Kułak, Rozstrzelany oddziat.

${ }^{28}$ K. Krajewski, G. Wąsowski, Kapitan Romuald Rajs „Bury” a Białorusini, s. 93-115. Zob. też: iidem, Kpt. Romuald Rajs „Bury” na kartach książki.

${ }^{29}$ Na stronie 204 w recenzowanej książce mylnie występuje Piotr Demianiuk jako sołtys wsi zeznający w 1949 r. przed UB (zamiast Łukasz). 
aktywista komunistyczny. Przebieg jego egzekucji, a raczej przypuszczenie, że został „zlikwidowany” w stodole, ponieważ nie chciał udać się przed chatę Grzegorza Sacharczuka, dokąd wzywano rozpoznanych aktywistów, Ostapiuk przedstawia, nie podając żadnych źródeł. W dodatku w tekście przytoczonej w książce relacji świadka znajduje się sugestia, że Fiodor Sacharczuk był „trochę mało rozwinięty” (s. 205, Autor nie komentuje tej informacji).

Pojawiają się także następne pytania, które wynikają głównie $\mathrm{z}$ analizy logicznej tekstu: dlaczego w „wybitnie skomunizowanej wsi” partyzanci zidentyfikowali tylko trzech komunistycznych aktywistów (w tym jeden pochodził z innej miejscowości, drugi miał 16 lat, a w przypadku trzeciego Autor nie podaje żadnych dowodów na jego prokomunistyczną działalność)? W jaki sposób w tak „mocno powiązanej z Sowietami” (s. 199) miejscowości znalazł schronienie przed sowieckimi organami bezpieczeństwa Stefan Weremczuk - podczas okupacji sołtys wsi Wólka Terechowska, który wydał Niemcom dziewięć osób współpracujących z sowiecką partyzantką? (s. 211-212).

Zaleszanie - zdaniem Ostapiuka - w większości usłuchali rozkazu o stawieniu się w chacie Sacharczuka, ponieważ myśleli, że mają do czynienia z KBW (choć wcześniej okazywali pozorowanemu reżimowemu wojsku lekceważenie). Czy oznacza to, że gdyby mieli świadomość, że rozkaz wydają uzbrojeni członkowie polskiego podziemia, zbojkotowaliby takie wezwanie? W książce została wyrażona pewność, że mieszkańcy do momentu podpalenia wsi byli przekonani, iż mają do czynienia z reżimowym wojskiem. Jednak przeczy temu treść znanego Autorowi książki (bo pojawiającego się w przypisach), choć niecytowanego fragmentu protokołu przesłuchania Eugenii Bazyluk z 19 lipca 1949 r. Przy okazji opisu przedpołudniowego pobytu partyzantów w jej domu kobieta zeznała:

zwracając się do swojej córki powiedziałam, żeby przyniosła krzesło z pokoju do kuchni, córka powtórzyła moje słowa, lecz po białorusku, wtenczas jeden z tych osobników powiedział: „co, nie możesz powiedzieć po polsku?” [--] ja dla nich postawiłam patelenkę z tłuszczem, jednocześnie mówiąc, że zgotowała by kaszy, lecz nie mam w domu cukru, wtenczas ten sam, co mówił o krześle wypowiedział się następujące słowa: „a co nie możecie mieć cukru, przecież macie wolną Polskę i tak słodko macie, czemu nie jedziecie do raju? [w znaczeniu do ZSRR - przyp. M.S.]". Z tych wypowiedzi zrozumiałam, że są to bandyci i już do nich nic nie mówiłam ${ }^{30}$.

30 AIPN Bi 212/2997, Protokół przesłuchania Eugenii Bazyluk z 19 VII 1949, t. 3, k. 277-278. 
Autor nie podejmuje szerzej wątku zebrania w chacie Sacharczuka. Z cytowanych relacji wynika, że „Bury” lub jego zastępca „Rekin” strzałem w sufit uciszył mieszkańców i poinformował ich, że wieś zostanie spalona. Jako powód podano zaangażowanie polityczne mieszkańców po stronie reżimu komunistycznego (s. 205). Czy oznacza to, że partyzanci zdekonspirowali się przed mieszkańcami na zebraniu? Bo chyba nie wydali podobnego komunikatu jako oficerowie z sowieckimi epoletami na ramionach? Być może taka konstatacja jest oczywista, jednak Ostapiuk o tym nie wspomina ${ }^{31}$.

W płonących zabudowaniach zginęło 14 osób, w tym siedmioro dzieci w wieku od dwóch tygodni do siedmiu lat. Według relacji świadków dwie kolejne osoby zostały zastrzelone podczas próby gaszenia pożaru. Autor biografii kpt. Rajsa napisał, że ofiar dałoby się uniknąć, gdyby wszyscy posłuchali bezwzględnego wezwania żołnierzy pozorowanego oddziału KBW i stawili się w domu Sacharczuka (s. 214). Tragedia nie była dziełem zamierzonym przez dowództwo - czytamy w książce. Z kolei, jeśli faktycznie doszło do zastrzelenia dwóch osób przez żołnierzy, musiała to być „indywidualna decyzja strzelających partyzantów, wykraczająca poza ramy otrzymanych rozkazów" (s. 213). Czy w takim razie kpt. „Bury” ukarał podkomendnych za tak rażące pogwałcenie dyscypliny? Konkluzja o „indywidualnej decyzji” partyzantów wydaje się zresztą zupełnie nielogiczna, gdy zestawimy ją z wcześniejszym opisem okoliczności wypuszczenia mieszkańców wsi z płonącego budynku Sacharczuka. Jeden z żołnierzy odchylił zabite gwoździami drzwi i umożliwił ludziom ucieczkę. Według Autora nie była to jego samodzielna inicjatywa, tylko musiał działać z rozkazu dowództwa, bowiem „znając dyscyplinę, jaka panowała w oddziale, taka samowola była raczej niemożliwa" (s. 210).

Przebieg wydarzeń w kolejnej miejscowości, Wólce Wygonowskiej, jest przedstawiony w książce jako niebudząca żadnych zastrzeżeń akcja żołnierze dowodzeni osobiście przez kpt. Rajsa spalili sześć budynków mieszkalnych oraz kilkanaście gospodarskich (nikt z mieszkańców nie

31 Podobnie sprawę zebrania w domu Sacharczuków przedstawiono w książce, która jest przywoływana w biografii kpt. „Rajsa”. Jej Autorzy - Mariusz Bechta i Wojciech J. Muszyński - piszą: „Z rozkazu «Burego» wszyscy mieszkańcy mieli stawić się na przymusowe zebranie resocjalizujące z komunizmu w domu sołtysa Dymitra Sacharczuka. Po wygłoszeniu przemówienia dowódca partyzantów, wobec niechętnej postawy zebranych, polecił zamknąć drzwi i okna oraz podpalić budynek. Po chwili partyzanci ostatecznie pozwolili spanikowanym ludziom wydostać się z płonącego budynku". W biografii „Rajsa” nie ma jednak informacji o zebraniu „resocjalizującym z komunizmu”. M. Bechta, W.J. Muszyński, op. cit., s. 268. 
zginął) oraz zastrzelili dwóch komunistycznych aktywistów, wskazanych prawdopodobnie przez pojmanych wcześniej wozaków białoruskich. Co prawda, jak przyznaje Ostapiuk: „istnieje niewielka możliwość, iż w obu przypadkach mogło dojść do pomyłki" (s. 217), to jednak „najważniejszy jest fakt, że likwidacji mężczyzn dokonano z powodów politycznych (abstrahując od tego, czy słusznie, czy nie) [wyróżnienie - M.S., s. 217]". Zdumiewające słowa. Czy oznacza to, że sam zamiar dokonania "likwidacji” z powodów politycznych usprawiedliwia czyny partyzantów, nawet jeśli okazałoby się, że ofiary były niewinne?

Również egzekucja 30 białoruskich furmanów wynikała według Autora jedynie z faktu, że pochodzili oni z „wybitnie skomunizowanych rejonów pow. bielskiego" (s. 223), a w trakcie rozmów z pozorowanym oddziałem KBW dowodzonym przez kpt. Rajsa zostali uznani za współpracowników reżimu komunistycznego. Ostapiuk, próbując wprowadzić element psychologizacji do wątku związanego z przeprowadzeniem przez żołnierzy „selekcji” wozaków (ci, którzy nie wykazali się tak dużą gorliwością po stronie reżimu zostali zwolnieni), uważa, że w rozmowach z KBW „furmani nie mieli powodu, by zatajać swoją ewentualną komunistyczną działalność" (s. 221). Jest to oczywiście jedna z możliwych hipotez, bo równie dobrze furmani mogli udawać lub wyolbrzymiać swoje zaangażowanie po stronie komunistów, aby przypodobać się trzymającym ich pod strażą wojskowym (i w ten sposób ochronić się przed ewentualnymi represjami).

Kolejne trzy wsie (Zanie, Szpaki i Końcowizna) zostały spacyfikowane na podstawie rozkazów, które przekazał swoim podkomendnym kpt. „Bury” na odprawie we wsi Łubnice (1 II 1946). Według Autora, zadania ograniczały się do „wyłuskania i ukarania [--] komunistycznej agentury". Jednak już podczas opisu akcji w Szpakach pojawia się informacja o zamiarze ukarania zbiorowo całej wsi za zaangażowanie polityczne, co znalazło wyraz nie tylko w spaleniu większości zabudowań, ale także w skierowaniu do mieszkańców pisemnego ultimatum o wyjeździe do ZSRR w ciągu 14 dni (s. 231). Po raz kolejny mamy więc do czynienia nie tylko z punktowym uderzeniem w „agentów”, ale także z zamiarem zastosowania odpowiedzialności zbiorowej wobec mieszkańców.

Z lektury książki nie wynika, czy partyzanci kontynuowali obraną wcześniej strategię grupy pozorowanej. W Szpakach 1. pluton ppor. „Wiarusa” pozbawił życia pięć osób uznanych za komunistów (część była uzbrojona), szósta zmarła w szpitalu. Według relacji świadków oraz dokumentów UB, żołnierze NZW usiłowali także zgwałcić siedemnastoletnią Marię Pietruczuk, a za stawiany opór ją zastrzelili. Według tych samych 
źródeł zgwałcili także jeszcze jedną, nastoletnią dziewczynę. Autor stara się oddalić ten poważny zarzut, choć przyznaje, że materiał nie pozwala tego „całkowicie wykluczyć” (s. 230). Jednocześnie jednak próbuje podważyć zarówno raport komisji badającej skalę zniszczeń w spalonej wsi, jak i relacje świadków oraz ich zeznania w toku przewodu sądowego. Poddaje także w wątpliwość ustalenia prokuratora IPN i zeznania zgwałconej ofiary złożone w 2004 r., ponieważ nie wynika z nich jasno, że sprawcą był polski partyzant. Po nakreślonych wątpliwościach czytelnik otrzymuje sugestię, że sprawa gwałtu mogła zostać spreparowana przez aparat komunistyczny. Upór, z jakim Ostapiuk stara się sprawę wyjaśnić na korzyść partyzantów NZW, nie cofa go nawet przed szokującym stwierdzeniem, że jeśli jednak siedemnastoletnia Pietruczuk została zabita przez podkomendnych kpt. Rajsa, to „powodem [--] mogło być jej polityczne zaangażowanie [wyróżnienie - M.S., s. 230]".

Najbardziej powściągliwy w obronie członków 3. Brygady NZW jest wątek w podrozdziale dotyczącym przebiegu wydarzeń w Zaniach, gdzie - jak pisze Autor - „doszło do niekwestionowanej tragedii” i zginęły „niewinne ofiary”. Realizujący zadania w tej miejscowości pluton pod dowództwem ppor. Jana Boguszewskiego „Bitnego” strzelał „z pełną premedytacją" (s. 235) nie tylko do ludzi, których uznano za współpracowników reżimu komunistycznego, ale także do zupełnie przypadkowych osób. Śmierć poniosły 24 osoby $-\mathrm{z}$ czego ponad połowę stanowiły kobiety i dzieci. Zdaniem Ostapiuka wina za taki przebieg wydarzeń leży po stronie ppor. „Bitnego”: „potrafił posuwać się do czynów, które nie mogą być akceptowane i których nie może usprawiedliwiać walka prowadzona z okupantem" (s. 233). Jednak i w tym przypadku Autor nie powstrzymuje się od sugestii, że po części winni są także mieszkańcy, którzy podjęli obronę (grupa miejscowych mężczyzn ostrzelała wchodzący do wsi pluton) oraz „żywiołowy rozwój sytuacji we wsi”, który powstał po tym, jak padły z obu stron strzały (s. 235). W pełni zaś usprawiedliwia kpt. Rajsa, który jako dowódca 3. Brygady NZW nie mógł przewidzieć działań ppor. „Bitnego”, bo „nie wiedział, na co stać człowieka, któremu powierzono spalenie Zań" (s. 233). Po raz kolejny powraca więc pytanie o „żelazną dyscyplinę” (s. 324) wewnątrz brygady. Skoro „Bitny” jeszcze w 1945 r. dopuścił się zbrodni - zastrzelił ujawniających się członków AK i był znany w brygadzie jako zimny likwidator, dla którego „zabijanie na zimno nie stanowiło żadnego problemu” (s. 233), dlaczego dowództwo nie przewidziało dla niego żadnej kary dyscyplinarnej? Dlaczego nie został ukarany jeszcze w 1945 r. za zabicie polskich żołnierzy? Dlaczego wreszcie nie został ukarany za zbrodnię w Zaniach? Trudno uwierzyć, aby kpt. Rajs - jak sugeruje Ostapiuk - nie poznał szczegółów 
jej przebiegu. Musiałaby zapanować zmowa milczenia w całym plutonie ppor. „Bitnego” i absolutny brak informacji z zewnątrz, a przecież spalenie wsi w powiecie bielskim szybko obiło się szerokim echem wśród lokalnej społeczności i w ówczesnej prasie ${ }^{32}$.

Ostatnia miejscowość - Końcowizna - została spalona pod osobistym dowództwem kpt. „Burego” (2 II 1946). Wieś nie była objęta rozkazem komendanta okręgu mjr. „Kotwicza” z września 1945 r. Według Ostapiuka powodem pacyfikacji był fakt, że w miejscowości tej istniała zagrażająca podziemiu samoobrona. Autor z przekonaniem określa ją jako „uzbrojoną bojówkę komunistyczną”, ponieważ jej członkowie mieli zgodę na zakup broni od władz. Partyzanci nie weszli do wsi, gdyż uzbrojeni mieszkańcy otworzyli do nich ogień. Autor ocenia, że kpt. „Bury” „zachował się bardzo rozsądnie. Zrezygnował z zajęcia niepokornej wsi, unikając tym samym śmierci niewinnych osób" (s. 238). Jest to jednak znów tylko przypuszczenie. Nie wiemy przecież, czym kierował się dowódca oddziału - czy odstąpił od tego zamiaru, faktycznie mając na względzie dobro mieszkańców, czy też nie pozwalały mu na to zaistniałe warunki strategiczne (ostrzał ze strony wsi). Niemniej jednak w Końcowiźnie nie było ofiar wśród cywilów, mieszkańcy zdołali uciec z płonących zabudowań. Spłonęło kilkadziesiąt budynków - głównie gospodarczych. Według Autora były one podpalane punktowo za pomocą pocisków zapalających.

W zakończeniu wątku dotyczącego pacyfikacji wsi w powiecie bielskim Ostapiuk sugeruje, że kryterium narodowościowo-wyznaniowe ofiar jest kalką myślową, której pierwowzór powstał jeszcze pod koniec lat czterdziestych XX w. w wyniku działań funkcjonariuszy UB i szeroko pojętego aparatu reżimu komunistycznego. Wskazywać mają na to m.in. tendencyjne zeznania różnych białoruskich świadków, spisywane w 1949 r. w sposób jednobrzmiący przez funkcjonariusza UB Bazylego Czuraka. Wielokrotnie powtarza się w nich zdanie: „bandy nad Białorusinami mścili się i pod groźbą broni użyciem, śmierci pod przymusem,

32 Tymczasem z zeznań Józefa Puławskiego „Gołębia” biorącego udział w spaleniu Zań wynika, że kpt. „Bury” po akcji zdyscyplinował jednego z partyzantów. Był nim właśnie „Gołąb”, który na czele swojej drużyny miał osłaniać wieś. Podczas realizacji rozkazu kilku ludzi z drużyny ruszyło do wsi i pomimo dyspozycji „Gołębia”, aby zostali na swoich miejscach, zaczęło pomagać w paleniu budynków. Puławski zeznał: „Dowódca plutonu «Bitny» powiedział «Buremu», że przeszkadzałem mu w wykonaniu jego rozkazu, gdyż nie dałem ludziom wejść do wsi. Za powyższy fakt zostałem przedstawiony do raportu i ukarany przez «Burego» karą podoficera służbowego przez okres trzech dni”, AIPN Bi 212/2997, t. 1, Protokół przesłuchania Józefa Puławskiego „Gołębia” z 1 II 1949, k. 265. 
wyganiali do Związku Radzieckiego". O ile z wielkim prawdopodobieństwem można przyjąć, że ówczesne władze na własny, polityczny użytek wykorzystywały wydarzenia z początku 1946 r. i mogły manipulować opisami ich przebiegu - nie można przypisać im autorstwa ulotek, w których oddział kpt. „Burego” faktycznie wzywał Białorusinów do opuszczenia Polski.

W pracy zastanawia obrana przez Autora metodologia oceny wiarygodności źródeł. Przykładowo uznaje on za dalece niewiarygodną niekorzystną dla polskich partyzantów relację córki jednej z ofiar z Wólki Wygonowskiej, opierającej się na słowach usłyszanych od własnej matki. Relacja ta jest dla Ostapiuka mniej wiarygodna niż zeznanie matki złożone w 1949 r. przed UB (s. 217). Jednocześnie relacja syna jednego z furmanów, który zapamiętał opowieść swojego ojca i przytaczał ją po latach przed prokuratorem IPN nie budzi żadnych wątpliwości (s. 219). Czasami Autor dezawuuje zeznania złożone przed UB, czasami przytacza je jako twarde dane, podpierając je twierdzeniami, że cytowany „w czasie śledztwa nie miał tajemnic przed UBP” (s. 237). Również niejasno interpretuje donosy agentów celnych. Raz są to wiarygodne źródła, raz nie. Można odnieść wrażenie, że nie wynika to z poszerzonej krytyki źródła, ale jest subiektywnym domniemaniem Autora na temat tego, czy ktoś mógł w danym momencie mówić prawdę, czy też nie.

$*$

Pomimo zapewnień, że ustalenia Ostapiuka „w zdecydowany sposób zmieniają dotychczasową wiedzę na temat przebiegu pacyfikacji i roli «Burego»" (s. 8), najważniejszy element się nie zmienia: ofiarami konkretnych działań żołnierzy NZW stali się niewinni ludzie. Jeśli pominiemy rozważania na temat motywów narodowościowo-wyznaniowych, to w zasadzie cała różnica interpretacyjna wydarzeń w powiecie bielskim zaproponowana w recenzowanej książce sprowadza się do tego, czy tego typu akcje represyjne przeprowadzane przez oddziały partyzantki są aktem, który z dzisiejszej perspektywy i na gruncie naukowym historyk może próbować usprawiedliwiać.

W książce wielokrotnie można spotkać się ze stwierdzeniem, że działania wymierzone w przedstawicieli miejscowej ludności były rzeczą przykrą, ale konieczną dla funkcjonowania polskich partyzantów. Oddziały leśne rzadko prowadziły walkę w otwartym polu, głównie zwalczały funkcjonariuszy aparatu represji, członków partii i osoby zaangażowane po stronie wroga (np. konfidentów). W ten sposób podtrzymywano morale wśród społeczeństwa i dawano czytelny znak, że należy zwalczać „zdrajców ojczyzny”. Są to argumenty poniekąd dobrze oddające warunki 
i metody funkcjonowania polskiego podziemia. Jednak w rękach historyków, którzy angażują się po jednej stronie opisywanych wydarzeń, jest to także bardzo wygodna kazuistyka. Bo oto w obronie kpt. „Burego” można każdego zabitego mieszkańca wsi, w której działała przed wojną jaczejka KPZB, a po wojnie oddział Samopomocy Chłopskiej czy koło PPR, zaliczyć na poczet ofiar walki z reżimem i zdrajcami ojczyzny. W takim ujęciu w pięciu wsiach powiatu bielskiego partyzanci działali w stanie spowodowanym wyższą koniecznością - zagrożeniem ze strony ludności, która stała się celem ich ataków. Tylko kiedy zejdziemy już na poziom konkretnych ofiar, to wśród nich możemy wyróżnić: a) osoby, co do których Autor przytacza oparte na bazie źródłowej informacje, że byli współpracownikami reżimu; b) tych, których partyzanci, kpt. „Bury”, lub być może sam Autor uznali za takich; c) pozostałych - bezsprzecznie niewinne ofiary, w tym kobiety i dzieci. Z lektury książki wynika, że ostatnie dwie kategorie są w zdecydowanej większości.

Czy śmierć tych ludzi można położyć na karb powojennego chaosu, brutalizacji, ciężkich warunków, w jakich operowali zastraszani i ścigani przez władze komunistyczne członkowie konspiracji? Czy okolicznością łagodzącą jest stwierdzenie, że „«Bury» był w stanie bezlitośnie traktować ludzi, ale tylko tych, których uznał za wrogów Ojczyzny. Nie kierował się religią czy narodowością, a zwalczał tylko osoby działające na niekorzyść państwa polskiego lub dopuszczające się zbrodni na ludności polskiej" (s. 195)? W kontekście niewinnych ofiar akcji w Zaleszanach, Szpakach i Zaniach zdanie takie nabiera sensu odwrotnego do zamierzonego przez Autora. Z kolei argument o „ciężkich czasach”, w których przyszło żyć bohaterowi książki, a których nie sposób oceniać z dzisiejszej perspektywy, tylko na pierwszy rzut oka wydaje się być słuszną krytyką historycznego prezentyzmu. Jednocześnie jednak Autor nie szczędzi wysiłków, aby usprawiedliwić działania Rajsa i narzucić tym samym czytelnikowi „właściwą” ocenę tej postaci.

Kapitan Rajs „Bury” jako dowódca 3. Brygady NZW ponosi odpowiedzialność za działania swoich podkomendnych, nawet jeśli nie zawsze był obecny podczas opisywanych wydarzeń (s. 241). W Zaleszanach wyraził zgodę na spalenie wsi (rozwiązanie takie miał mu podsunąć jego zastępca „Rekin”), w Zaniach i Szpakach partyzanci z plutonów ppor. „Wiarusa” i ppor. „Bitnego” działali na jego rozkaz. Decyzja o zastosowaniu odpowiedzialności zbiorowej, spaleniu wsi i groźbach nakazujących trwałe opuszczenie swoich domostw przez mieszkańców w sposób oczywisty doprowadziła do takiego rozwoju wypadków, które musiały skutkować cierpieniem ludności cywilnej. Dodajmy również, że część członków Komendy Okręgu NZW „Chrobry” negatywnie oceniła działania 
szefa PAS kpt. „Burego”, uważając, że przekroczył on wydane rozkazy i kompetencje ${ }^{33}$.

Czy można zakładać, że sytuacja rozwinęła się w niepomyślnym kierunku i dowódcy nie udało się nad nią zapanować? Po pierwszej pacyfikacji w Zaleszanach partyzanci nie zostali w żaden sposób upomniani, w kolejnych miejscowościach stosowano dokładnie tę samą taktykę palenia wsi, która zawsze mogła powtórzyć tragedię, której - zdaniem Autora - kpt. „Bury” chciał przecież uniknąć. Nie było to więc działanie punktowe, polegające na otoczeniu i przeczesaniu miejscowości w poszukiwaniu osób, które zagrażały partyzantom, tylko podyktowane kilkoma nakładającymi się na siebie przesłankami (w tym negatywnym postrzeganiem „komunizującej” ludności białoruskiej) oraz uznaniowością działanie połączone - powtórzmy - z zastosowaniem odpowiedzialności zbiorowej. W tak skonstruowanej narracji umyka oczywista, zdawać by się mogło, konstatacja: zbrodnia na ludności cywilnej - bez względu na narodowość sprawców i ofiar, bez względu na jej motywację, w wymiarze uniwersalnym i etycznym powinna być zawsze obiektem potępienia. Dotyczy to także przypadków, gdy granica pomiędzy eufemistycznym „likwidowaniem wrogów i współpracowników reżimu”, a zabijaniem niewinnych ludzi jest bardzo cienka, lub nie ma jej wcale. Autor co prawda ubolewa, że w Zaleszanach i Zaniach doszło do tragedii i zginęli przypadkowi ludzie. Jednak jednocześnie z niepokojem należy odebrać szukanie w książce uzasadnień dla popełnienia podobnych czynów, a już zwłaszcza próbę przenoszenia ciężaru winy ze sprawców na ofiary.

Dlaczego, moim zdaniem, uczciwe przedstawienie działań partyzantów 3. Brygady NZW biorących udział w pacyfikacji pięciu wsi w powiecie bielskim jest tak ważne? Ponieważ próba usprawiedliwienia podobnych zbrodni otwiera niebezpieczne pole do relatywizacji ocen różnych formacji czy grup zbrojnych, w wyniku których ucierpiała ludność cywilna (bez względu na skalę tych działań oraz narodowość, wyznanie czy światopogląd ofiar). Chciałabym zwrócić uwagę, że uznając podobną argumentację jako dopuszczalną w polskiej historiografii, kapituluje się jednocześnie przed tymi, którzy, przykładowo, wybielają zbrodnie popełnione na polskiej (i nie tylko) ludności przez ukraińskich nacjonalistów czy oddziały sowieckiej partyzantki. Wreszcie - jeśli przyjmiemy, że podobne czyny podlegają eksplikacji, należy zadać jeszcze jedno pytanie: jak plasować działania PAS NZW pod dowództwem kpt. Rajsa na tle

${ }^{33}$ Komendant okręgowy NZW ppłk Władysław Żwański „Błękit”, który 4 kwietnia 1946 r. zastąpił na tym stanowisku mjr „Kotwicza”, sprawę odłożył do wyjaśnienia „po zwycięstwie”, M. Bechta, W.J. Muszyński, op. cit., s. 267. 
pozostałych oddziałów polskiego podziemia, które nie uciekały się do takich metod?

Trudno także zgodzić się z sugestią Ostapiuka, że od 1989 r. mamy do czynienia z manichejską walką pomiędzy czarną i białą legendą kpt. Rajsa, a opowiedzenie się po którejś ze stron jest zdeterminowane przez balast „fałszywych opinii” o tym żołnierzu spreparowanych przez poprzedni system (skoro komuniści niszczyli i zohydzali pamięć o podziemiu niepodległościowym, zadbali także o to, aby obarczyć „Burego” grzechem niewinnych ofiar). Tak narzucony dyskurs wypacza w ogóle sens dyskusji, bo każdy adwersarz nakreślonej przez Autora oceny działań „Burego” staje się automatycznie obrońcą „komunistycznej” wizji jego życiorysu. Zamiast pogłębionej refleksji podejmowane są próby angażowania historyków na polu polityki historycznej, co skutkuje podziałem na tych, którzy są „za” kpt. Rajsem i „przeciwko” niemu. Tych, którzy spełniają patriotyczny obowiązek i restytuują jego dobre imię oraz tych, którzy „atakują go" z niecnych powodów - bo np. wywodzą się ze środowisk lewicowych i powielają narrację komunistów i „ubeków”. Tymczasem życiorys kpt. Rajsa nie jest jednobarwny. Autor zdaje się tego nie dostrzegać, stąd też w narracji książki wydarzenia z zimy $1946 \mathrm{r}$. stają się zakładnikiem spiżowego obrazu bohatera, a wszyscy przeciwnicy takiego rozwiązania - zakładnikami kreowanej w tym względzie „polityki historycznej”.

Warto więc zadać pytanie: czy w środowisku historyków możliwa jest dziś rzeczowa dyskusja wokół postaci kpt. Romualda Rajsa „Burego”, która jednoznacznie potępi tragiczne wydarzenia, do których doszło w początkach 1946 r.? Niestety, wnioski formułowane przez Michała Ostapiuka w recenzowanej części książki nie napawają w tej sprawie optymizmem.

\section{Streszczenie}

Artykuł recenzyjny dotyczy książki autorstwa Michała Ostapiuka Komendant „Bury”. Biografia kpt. Romualda Adama Rajsa „Burego”(1913-1949) (Olsztyn-Warszawa 2019) i koncentruje się na powojennej części biografii Rajsa poświęconej jego działalności na terenie Białostocczyzny. Najbardziej znanym wątkiem z tego okresu jest spacyfikowanie przez oddział dowodzony przez „Burego” (3. Brygada Narodowego Zjednoczenia Wojskowego) pięciu białoruskich wsi w powiecie Bielsk Podlaski na przełomie stycznia i lutego 1946 r. W wyniku tych działań śmierć poniosło 79 mieszkańców, w tym kobiety i dzieci. Autor biografii stara się usprawiedliwić partyzantów, wskazując na polityczny charakter tych działań (walka z komunizmem) i zagrożenie, jakie płynęło dla NZW ze strony białoruskiej, „skomunizowanej” ludności. Polemika zawarta 
w artykule recenzyjnym dotyczy opisu działań 3. Brygady NZW w pięciu wsiach: Zaleszany, Wólka Wygonowska, Szpaki, Zanie i Końcowizna w początkach 1946 r. oraz ich interpretacji, w tym odrzucenia przez Autora kryterium narodowościowego jako jednego z czynników sprawczych. Najważniejszym punktem poddanym krytyce jest nieuwzględnienie przez Autora książki pojęcia zbrodni na ludności cywilnej jako terminu odnoszącego się do działań formacji zbrojnych wobec ludności cywilnej.

\section{A Pacification of Five Villages. On the Dark Chapters of Biography of Capt. Romuald Rajs aka Bury}

This review article presents Michał Ostapiuk's book Komendant „Bury”. Biografia kpt. Romualda Adama Rajsa „Burego” (1913-1949) (Olsztyn and Warsaw, 2019), and focuses primarily on the post-war part of Rajs's life and his military activities in the Białystok region. The best-known episode of this period is a pacification made by the unit commanded by Bury (Third National Military Union Brigade) of five Belarusian villages in the Bielsk Podlaski district in late January and early February of 1946. As a result, seventy-nine peasants were killed, including women and children. The Author of the biography tries to justify the guerrillas, indicating the political character of these actions (their struggle against communism) and the threat posed to the National Military Union by the Belarusian 'communized' people. The polemics of the review article concerns the description of operations of the Third National Military Union Brigade in the five villages of Zaleszany, Wólka Wygonowska, Szpaki, Zanie, and Końcowizna in early 1946 and their interpretations, including the rejection by the Author of the criterion of nationality as one of the causative factors. The most crucial point under criticism is the Author's failure to recognize the concept of crime against civilians as the term referring to the activities of armed formations against civilians.

\section{Bibliografia}

Bandzo Józef, Tak było. Wspomnienia partyzanta 3. i 5. Wileńskiej Brygady Armii Krajowej, Fundacja Niepodległości, Lublin 2015.

Bechta Mariusz, Muszyński Wojciech J., Przeciwko Pax Sovietica. Narodowe Zjednoczenie Wojskowe i struktury polityczne ruchu narodowego wobec rezimu komunistycznego 1944-1956, IPN-KŚZpNP, Warszawa 2017.

Broński Zdzisław, Pamiętnik (wrzesień 1939 - maj 1949), wstęp i oprac. Sławomir Poleszak, IPN-KŚZpNP, Lublin-Warszawa 2015.

Choruży Wiesław, Spalenie wsi Zanie przez oddział PAS NZW kpt. Romualda Rajsa „Burego”, „Białoruskie Zeszyty Historyczne” 2002, 18, s. 167-177.

Iwaniuk Sławomir, Zbrodnie oddziału PAS NZW dowodzonego przez Romualda Rajsa ps. „Bury” popetnione na Białorusinach w styczniu-lutym 1946 r. w dokumentach polskich władz komunistycznych, „Białoruskie Zeszyty Historyczne” 1997, 8, s. 122-180. 
Kalisz Piotr, Łapiński Piotr, Polskie podziemie niepodległościowe wobec ludności białoruskiej na Białostocczyźnie po 1944 r. (zarys problematyki), w: Stosunki polsko-białoruskie w województwie białostockim w latach 1939-1956, red. Jan J. Milewski, Anna Pyżewska, IPN-KŚZpNP, Warszawa 2005.

Kłosiński Zygmunt, 3. Wileńska, Red. „Gońca Kresowego”, Białostocki Oddz. Tow. Przyjaciół Grodna i Wilna, Białystok 1995.

Krajewski Kazimierz, Łabuszewski Tomasz, „Łupaszka”, „Młot”, „Huzar”. Działalność 5 i 6 Brygady Wileńskiej AK (1944-1952), Volumen, Warszawa 2002.

Krajewski Kazimierz, Na straconych posterunkach. Armia Krajowa na Kresach Wschodnich II Rzeczypospolitej, Wydawnictwo Literackie, Kraków 2015.

Krajewski Kazimierz, Wąsowski Grzegorz, Kapitan Romuald Rajs „Bury” a Białorusini fakty i mity, „Glaukopis” 2016, 33, s. 93-115.

Krajewski Kazimierz, Wąsowski Grzegorz, Kpt. Romuald Rajs „Bury” na kartach ksiażki „Skazy na pancerzach”, czyli prawda wedtug Piotra Zychowicza, http://podziemiezbrojne.blox.pl/resource/Bury_vs_Zychowicz.2018.pdf (dostęp: 4 IV 2019).

Kułak Jerzy, Romuald Adam Rajs (1913-1949), w: Konspiracja i opór społeczny w Polsce 1944-1956. Słownik biograficzny, t. 2, IPN, Kraków 2004, s. 432-439.

Kułak Jerzy, Rozstrzelany oddziat. Monografia 3 Wileńskiej Brygady NZW. Białostocczyzna 1945-1946, nakł. autora, Białystok 2007; Rozstrzelany oddział. 3. Wileńska Brygada NZW kapitana Rajsa „Burego”. Białostocczyzna 1945-1946, Oficyna Wydawnicza Mireki Andrzej Mirecki, Warszawa 2015 (wyd. 2).

Mazur Mariusz, Antykomunistycznego podziemia portret zbiorowy 1945-1956. Aspekty mentalno-psychologiczne, Bellona, Lublin 2019.

Mironowicz Eugeniusz, Białorusini w Polsce 1944-1949, PWN, Warszawa 1993.

Mironowicz Eugeniusz, Polityka władz polskich wobec Białorusinów. Stosunek ludności białoruskiej do państwa polskiego (1944-1956), w: Stosunki polsko-białoruskie w województwie białostockim w latach 1939-1956, red. Jan J. Milewski, Anna Pyżewska, IPN-KŚZpNP, Warszawa 2005, s. 65-78.

Mironowicz Eugeniusz, Tokć Siarhiej, Radzik Ryszard, Zmiana struktury narodowościowej na pograniczu polsko-białoruskim w XX wieku, Wydawnictwo Uniwersytetu w Białymstoku, Białystok 2005.

Moroz Anna, Między pamięcia a historia. Konflikt pamięci zbiorowych Polaków i Białorusinów na przykładzie Romualda Rajsa „Burego”, IPN-KŚZpNP, Warszawa 2016.

Motyka Grzegorz, Na białych Polaków obława. Wojska NKWD w walce z polskim podziemiem 1944-1953, Wydawnictwo Literackie, Kraków 2014.

Niwiński Piotr, Czarne karty podziemia poakowskiego. Problemy demoralizacji członków konspiracji niepodległościowej po 1945 r., w: Podziemie zbrojne na Lubelszczyźnie wobec dwóch totalitaryzmów 1939-1956, red. Sławomir Poleszak, Adam Puławski, IPN, Warszawa 2002, s. 99-111.

Niwiński Piotr, Garnizon Konspiracyjny Miasta Wilna, Adam Marszałek, Toruń 2000. Ostapiuk Michał, Komendant „Bury”. Biografia kpt. Romualda Adama Rajsa „Burego” (19131949), Białystok-Olsztyn-Warszawa 2019.

Poleszak Sławomir, Podziemie antykomunistyczne w Łomżyńskiem i Grajewskiem (19441947), Volumen, Warszawa 2004.

Rokicki Paweł, Armia Krajowa na Wileńszczyźnie 1943-1945, Barwa i Broń, Warszawa 2007. 
Tomaszewski Longin, Wileńszczyzna lat wojny i okupacji 1939-1945, Rytm, Warszawa 2010.

Wnuk Rafał, Problem bandytyzmu wśród żołnierzy antykomunistycznego podziemia w Polsce (1944-1947), w: Komunizm, ideologia, system, ludzie, red. T. Szarota, Neriton, IH PAN, Warszawa 2001, s. 67-79.

Zajączkowski Mariusz, Pod znakiem króla Daniela. OUN-B i UPA na Lubelszczyźnie 19441950, IPN-KŚZpNP, ISP PAN, Lublin-Warszawa 2016.

Zaremba Marcin, Wielka Trwoga. Polska 1944-1947. Ludowa reakcja na kryzys, Znak, ISP PAN, Kraków 2012.

„Żeby Polska była polska!” Antologia publicystyki konspiracyjnej podziemia narodowego 1939-1950, wstęp, wybór i oprac. Marek J. Chodakiewicz, Wojciech J. Muszyński, IPN-KŚZpNP, Warszawa 2010.

Biogr a m: Magdalena Semczyszyn (ur. 1982) - dr, pracownica Oddziałowego Biura Badań Historycznych Instytutu Pamięci Narodowej w Szczecinie. Autorka publikacji dotyczących m.in. relacji międzyetnicznych na ziemiach polskich w XIX i XX w.; kontakt: magdalena.semczyszyn@ipn.gov.pl. 